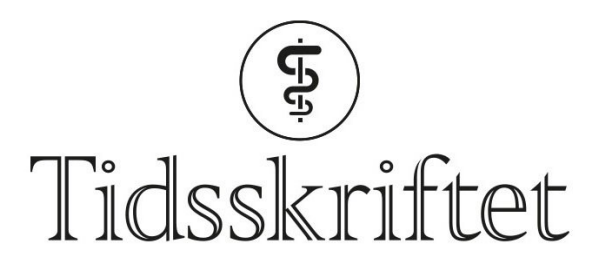

DEN NORSKE LEGEFORENING

\title{
Bruk av ultralydapparat i lommeformat ved karkirurgi
}

KORT RAPPORT

\section{HENRIETTE FAGERTUN}

E-post: henriette.fagertun@stolav.no

Karkirurgisk seksjon

St. Olavs hospital

og

Nasjonal kompetansetjeneste for ultralyd og bildeveiledet behandling

Institutt for sirkulasjon og bildediagnostikk

NTNU

Henriette Fagertun er spesialist i generell kirurgi, konstituert overlege og universitetslektor i

karkirurgi.

Forfatteren har fylt ut ICMJE-skjemaet og oppgir ingen interessekonflikter.

\section{CECILIE VÅPENSTAD}

Nasjonal kompetansetjeneste for ultralyd og bildeveiledet behandling Institutt for sirkulasjon og bildediagnostikk

NTNU

og

Gruppe for medisinsk teknologi

SINTEF Helse

Cecilie Våpenstad er sivilingeniør i medisinsk teknologi og forsker.

Forfatteren har fylt ut ICMJE-skjemaet og oppgir ingen interessekonflikter.

\section{REIDAR BREKKEN}

Nasjonal kompetansetjeneste for ultralyd og bildeveiledet behandling Institutt for sirkulasjon og bildediagnostikk

NTNU

og

Gruppe for medisinsk teknologi

SINTEF Helse

Reidar Brekken er ph.d. i medisinsk teknologi og seniorforsker.

Forfatteren har fylt ut ICMJE-skjemaet og oppgir ingen interessekonflikter.

\section{TORBJØRN DAHL}

Karkirurgisk seksjon

St. Olavs hospital

og

Nasjonal kompetansetjeneste for ultralyd og bildeveiledet behandling

Institutt for sirkulasjon og bildediagnostikk

NTNU

Torbjørn Dahl er spesialist i karkirurgi og avdelingssjef.

Forfatteren har fylt ut ICMJE-skjemaet og oppgir ingen interessekonflikter. 


\section{BAKGRUNN}

Ultralyd er mye brukt innen karkirurgi. Sammenlignet med konvensjonelle ultralydapparat har lommeultralydapparat begrenset funksjonalitet, men er billigere og enkle å bære med seg. Hensikten med studien var å undersøke om karkirurger kunne ha nytte av lommeultralydapparat i en klinisk hverdag.

\section{MATERIALE OG METODE}

Ultralydapparat i lommeformat var tilgjengelig ved Karkirurgisk seksjon ved St. Olavs hospital i en timånedersperiode. Elleve leger deltok, og de stod fritt til å velge konvensjonelt ultralydapparat eller lommeultralydapparat. Etter hver bruk av lommeultralydapparat registrerte deltagerne problemstilling, om denne ble besvart, opplevd bildekvalitet og behov for supplerende bildediagnostikk i et registreringsskjema. Etter endt studieperiode besvarte brukeren et spørreskjema.

\section{RESULTAT}

Lommeultralydapparat ble hovedsakelig brukt preoperativt. Problemstillingen ble besvart med lommeultralydapparat i 51 ( $85 \%$ ) av totalt 6 o registrerte unders $\varnothing$ kelser. Bildekvaliteten ble subjektivt vurdert som god i 32 (53\%), middels i 21 (35\%) og lav i 7 (12\%) av undersøkelsene, med besvart problemstilling i henholdsvis $94 \%$, $90 \%$ og $29 \%$ av tilfellene. Leger med under fem års ultralyderfaring valgte oftere lommeultralyd sammenlignet med mer erfarne brukere.

\section{FORTOLKNING}

For de valgte undersøkelsene gav lommeultralydapparat stort sett tilstrekkelig bildekvalitet og besvarte ofte de aktuelle kliniske problemstillingene. Lommeultralydapparat kan være et nyttig supplement innen karkirurgi, særlig for veneundersøkelser.

Ultralydapparat i lommeformat har vært på markedet i omkring ti år. Prisen på lommeultralydapparat er relativt lav sammenlignet med prisen på konvensjonelle ultralydapparat, lommeapparat er lette å ta med seg, og det trengs lite opplæring for å ta dem i bruk. Funksjonaliteten er noe lavere i forhold til konvensjonelle apparat, med et begrenset utvalg prober, lavere penetrasjon, lavere oppløsning, mindre skjerm og manglende hastighetsmåling. Likevel har lommeultralydapparatet vist seg å være et nyttig verktøy i flere kliniske situasjoner. Både for ekkokardiografi $(1,2)$ og intraabdominale undersøkelser (3) er det vist at undersøkelser med lommeapparat kan være nyttig og kostnadseffektivt for screening og enklere diagnostikk (4).

Innen karkirurgi har lommeultralydapparat vist seg å være nyttig for screening av abdominale aneurismer og måling av aneurismediameter $(5,6)$ samt ved diagnose av komplikasjoner etter innstikk i lårpulsåren ved koronar angiografi (7).

Hensikten med vår studie var å undersøke om karkirurger i vanlige kliniske situasjoner kunne ha nytte av lommeultralydapparat.

\section{Materiale og metode}

Karkirurgisk seksjon ved St. Olavs hospital har ti senger. Operativ virksomhet omfatter åpen og endovaskulær aortakirurgi, perifer karkirurgi og åpen og endovenøs åreknutekirurgi. I 2017 ble det utført rundt 250 åpne arterielle inngrep. Konvensjonelle ultralydapparat er tilgjengelige i poliklinikk, akuttmottak og operasjonsstuer. Bruk av ultralydapparat på sengepost, ved operative inngrep eller i vaktsammenheng er en integrert del av virksomheten og registreres ikke.

En prospektiv studie ble utført i perioden fra mai 2017 til februar 2018. Alle legene (totalt elleve) som utførte ultralydundersøkelser ved avdelingen, deltok. To lommeultralydapparat 
av typen Vscan Dual Probe (GE Vingmed Ultrasound, Horten, Norge) ble plassert lett tilgjengelig på sengeposten. Vscan-apparatet har to transdusere i samme probe. Den til overfladisk bruk har et eget vaskulært program, med frekvens fra 3,4 til 8,o MHz. Det er ingen funksjon for hastighetsmåling, men en fargedopplerfunksjon. Et introduksjonskurs av én times varighet ble holdt før oppstart.

Deltagerne stod fritt til å velge konvensjonelt ultralydapparat eller lommeultralydapparat ved ultralydundersøkelser. Etter hver bruk av lommeapparatet ble et registreringsskjema fylt ut for å registrere blant annet følgende opplysninger: type problemstilling (ti forhåndsdefinerte indikasjoner), om problemstillingen ble besvart (ja eller nei), subjektivt opplevd bildekvalitet (god, middels eller dårlig), eventuelt behov for supplerende bildediagnostikk (ultralyd, CT eller annet) og undersøkerens ultralyderfaring ( $<1$ år, 1-3 år, 3-5 år eller $>5$ år) (se registreringsskjema i appendiks 1). Fra journalgjennomgang hentet vi ut et estimat på antall operasjoner som krevde preoperativ ultralydmarkering (tabell 1).

\section{Tabell 1}

Antall ultralydundersøkelser gjennomført med lommeultralydapparatet Vscan i studieperioden og i hvilken grad problemstillingen ble besvart ved bruk av Vscanapparatet, fordelt på åtte av ti indikasjoner (to forhåndsbestemte indikasjoner hadde ingen undersøkelser). For noen indikasjoner foreligger totalt antall utførte ultralydundersøkelser, da det alltid gjøres ultralydundersøkelse ved disse.

\begin{tabular}{|c|c|c|c|}
\hline Indikasjon & $\begin{array}{c}\text { Totalt antall } \\
\text { ultralydundersøkelser } \mathrm{i} \\
\text { perioden }\end{array}$ & $\begin{array}{c}\text { Utført med } \\
\text { Vscan-apparat }\end{array}$ & $\begin{array}{c}\text { Problemstilling } \\
\text { besvart med } \\
\text { Vscan-apparat }\end{array}$ \\
\hline $\begin{array}{l}\text { Markering av vener før } \\
\text { åreknutekirurgi }\end{array}$ & 60 & 15 & 14 (93 \%) \\
\hline $\begin{array}{l}\text { Kartlegging av vener før } \\
\text { bypasskirurgi }\end{array}$ & 13 & 10 & $10(100 \%)$ \\
\hline $\begin{array}{l}\text { Kartlegging av vene før } \\
\text { anleggelse av arteriovenøs } \\
\text { fistel }\end{array}$ & 27 & 10 & $8(80 \%)$ \\
\hline $\begin{array}{l}\text { Halspulsårevurdering } \\
\text { preoperativt (beliggenhet } \\
\text { av bifurkaturen, åpen } \\
\text { arteria carotis interna) }\end{array}$ & Ikke tilgjengelig' & 8 & $5(63 \%)$ \\
\hline $\begin{array}{l}\text { Vurdere pseudoaneurisme } \\
\text { lyske }\end{array}$ & Ikke tilgjengelig' & 6 & $5(83 \%)$ \\
\hline $\begin{array}{l}\text { Vurdere pseudoanurisme } \\
\text { håndledd }\end{array}$ & Ikke tilgjengelig' & 2 & $0(0 \%)$ \\
\hline $\begin{array}{l}\text { Kontroll av anlagt } \\
\text { femoropopliteal bypass }\end{array}$ & Ikke tilgjengelig' & 6 & $5(83 \%)$ \\
\hline Annet & & 3 & $4(100 \%)$ \\
\hline Totalt & & 60 & $51(85 \%)$ \\
\hline
\end{tabular}

${ }^{1}$ Vurdering av halspulsåre på operasjonsstue samt kontroll av femoropopliteal bypass gjøres etter operat $ø$ rs $\emptyset$ nske, og antall er ikke registrert. Antall vurderinger av pseudoaneurismer registreres ikke.

For å kartlegge hvorvidt konvensjonelt ultralydapparat eller lommeultralydapparat ble foretrukket, ble deltagerne etter endt studieperiode bedt om å fylle ut et spørreskjema (se appendiks 2). De vurderte hva slags apparat de foretrakk for de ulike indikasjonene som de fant aktuelle («Alltid et konvensjonelt ultralydapparat», «Alltid Vscan» eller "Det kommer an på»), samt hvilke faktorer som var avgjørende for valg av ultralydapparat (ni utsagn som ble bedømt på en skala fra 1 («Lite enig») til 5 («Veldig enig»)).

Regional komite for medisinsk og helsefaglig forskningsetikk (REK) vurderte studien som 


\section{Resultat}

Totalt 60 registreringsskjema ble fylt ut etter bruk av lommeultralydapparat.

Lommeapparat ble ikke brukt for alle forhåndsdefinerte indikasjoner. Samtlige elleve leger registrerte bruk av lommeapparat (2-18 undersøkelser per lege). Fire leger hadde ett-tre års erfaring med ultralyd, og sju leger over fem års erfaring.

Problemstillingen ble besvart i 51 (85\%) av de 6 o unders $\varnothing$ kelsene med lommeultralydapparat. Lommeapparat ble 35 av 6 o ganger brukt på venesiden - til preoperativ markering av vener før åreknutekirurgi, bypasskirurgi eller ved anleggelse av arteriovenøs fistel. Detaljerte resultat per indikasjon er oppsummert i tabell 1. Av 60 undersøkelser med lommeultralydapparat ble 43 gjort preoperativt, særlig i situasjoner hvor det var behov for markering av vener. I disse tilfellene ble problemstillingen besvart i 32 (91\%) av 35 tilfeller. Ved venemapping før bypasskirurgi ble lommeultralydapparat brukt i $10(77 \%)$ av 13 aktuelle tilfeller, alle med besvart problemstilling og uten behov for supplerende diagnostikk.

Bildekvaliteten ble vurdert som god i 32 (53\%) av undersøkelsene gjort med lommeultralydapparat, middels i 21 (35\%) og lav i 7 (12\%). For hver av disse kategoriene ble den kliniske problemstillingen besvart i henholdsvis 30 (94\%), 19 (90\%) og 2 (29\%) av tilfellene. Supplerende diagnostikk ble gjort i 12 tilfeller, men i kun 8 av disse var problemstillingen ikke besvart.

Gjennom spørreskjema utfylt etter endt registreringsperiode fant vi at forventning om utilstrekkelig bildekvalitet framstod som den viktigste grunnen til å avstå fra bruk av lommeultralydapparat (figur 1, median 5 , spredning 3-5). I de tilfellene hvor lommeapparat ble valgt, var særlig tilgjengelighet høyt verdsatt (median 5 , spredning 1-5). De syv legene med mer enn fem års ultralyderfaring foretrakk konvensjonelt apparat i 6o \% av tilfellene, mens tilsvarende tall for de med mindre enn fem års erfaring var $29 \%$.

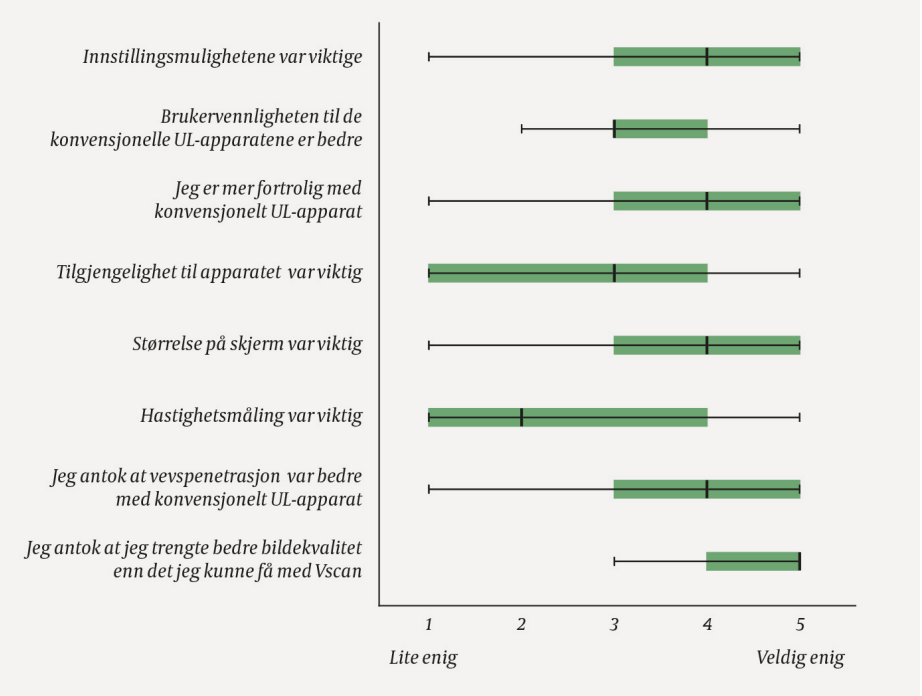

Figur 1 Boksplott av deltagernes svar på følgende spørsmål: «I en situasjon hvor du mente at Vscan ikke var godt nok: På en skala fra 1 (lite enig) til 5 (veldig enig), bedøm følgende utsagn i forhold til ditt valg». Spørsmålet ble stilt for hver indikasjon, og boksplottet viser svarene for alle indikasjonene til sammen. Påstanden «Fargedoppler var viktig» er ikke tatt med, da begge apperatene brukte fargedoppler. Boksplottet viser median, interkvartilbredde og variasjonsbredde.

\section{Diskusjon}

Dette er en deskriptiv studie av karkirurgers bruk av lommeultralydapparat, og ingen direkte sammenligning av konvensjonelle apparat og lommeapparat. Seleksjonsskjevhet 
mot at det primært var enklere undersøkelser som ble gjennomført med lommeultralydapparat, kan ikke utelukkes. Når lommeapparat ble valgt som første modalitet, var bildekvaliteten god eller middels i 53 av 60 unders $\varnothing$ kelser, og problemstillingen besvart i 51 av 60 .

Lommeultralydapparatet ble brukt mindre enn forventet i registreringsperioden. De mest erfarne legene valgte det oftere bort, grunnet et ønske om høy bildekvalitet.

Tilgjengeligheten til konvensjonelle ultralydapparat er god på vårt sykehus, noe som kan bidra til å forklare det relativt lave antallet undersøkelser med lommeultralydapparat i studieperioden. Mangel på hastighetsmåling, som er viktig for vurdering av arteriell blodstrøm, gjør også at det valgte lommeapparatet ikke kan erstatte et konvensjonelt apparat for alle indikasjoner.

Ved enklere undersøkelser innen karkirurgi, særlig på venesiden, kan imidlertid lommeultralydapparat være et nyttig supplement til konvensjonelt ultralydapparat.

\section{HOVEDFUNN}

Av 60 undersøkelser med lommeultralydapparat ble 35 utført på venesiden, og problemstillingen ble da besvart i $91 \%$ av tilfellene.

De resterende 25 undersøkelsene med lommeultralydapparat var på arteriell side og besvarte $76 \%$ av problemstillingene.

\section{LITTERATUR:}

1. Galusko V, Bodger O, Ionescu A. A systematic review of pocket-sized imaging devices: small and mighty? Echo Res Pract 2018; 5: 113-38. [PubMed][CrossRef]

2. Chamsi-Pasha MA, Sengupta PP, Zoghbi WA. Handheld echocardiography: Current state and future perspectives. Circulation 2017; 136: 2178-88. [PubMed][CrossRef]

3. Tse KH, Luk WH, Lam MC. Pocket-sized versus standard ultrasound machines in abdominal imaging. Singapore Med J 2014; 55: 325-33. [PubMed][CrossRef]

4. Mjolstad OC, Dalen H, Graven T et al. Routinely adding ultrasound examinations by pocket-sized ultrasound devices improves inpatient diagnostics in a medical department. Eur J Intern Med 2012; 23: 185-91. [PubMed][CrossRef]

5. Phiri D, Mallow P, Rizzo JA. PMD65 the cost effectiveness of hand held ultrasound scanning for AAA in elderly subjects with a history of smoking. Value Health 2012; 15: A356. [CrossRef]

6. Dijos M, Pucheux Y, Lafitte M et al. Fast track echo of abdominal aortic aneurysm using a real pocketultrasound device at bedside. Echocardiography 2012; 29:285-90. [PubMed][CrossRef]

7. Filipiak-Strzecka D, Michalski B, Kasprzak JD et al. Pocket-size imaging devices allow for reliable bedside screening for femoral artery access site complications. Ultrasound Med Biol 2014; 40: 2753-8. [PubMed][CrossRef]

Publisert: 15. april 2020. Tidsskr Nor Legeforen. DOI: 10.4045/tidsskr.19.026o Mottatt 27.3.2019, første revisjon innsendt 17.9.2019, godkjent 18.2.2020.

(C) Tidsskrift for Den norske legeforening 2020. Lastet ned fra tidsskriftet.no 